\title{
Serum zinc deficiency and associated factors among pre-ART and on-ART adults at Felege Hiwot referral hospital, Bahir Dar, Northwest Ethiopia
}

\author{
Abera Ademasu', Bizuayehu Kerisew², Endalkachew Nibret ${ }^{2}$, Abayneh Munshea $^{2}$, \\ Melaku Adal, ${ }^{2, *}$ \\ ${ }^{1}$ Bahir Dar Health Science College, department of Medical laboratory Technology, Bahir Dar, Ethiopia \\ ${ }^{2}$ University of Bahir Dar, College of Science, department of Biology, Bahir Dar, Ethiopia
}

\section{Email address:}

aberaademasu@yahoo.com (A. Ademasu),bizushk@yahoo.com (B. Kerisew),endtg2002@yahoo.com (E. Nibret), abitew2010@gmail.com (A. Munshea),melakuadal@yahoo.com (M. Adal)

To cite this article:

Abera Ademasu, Bizuayehu Kerisew, Endalkachew Nibret, Abayneh Munshea, Melaku Adal. Serum Zinc Deficiency and Associated Factors among Pre-ART and on-ART Adults at Felege Hiwot Referral Hospital, Bahir Dar, Northwest Ethiopia. International Journal of Nutrition and Food Sciences. Vol. 3, No. 4, 2014, pp. 311-317. doi: 10.11648/j.ijnfs.20140304.22

\begin{abstract}
Background: Among several trace elements, zinc is a micronutrient that has a very significant role in maintaining immune function. Studies investigating trace elements status in people living with HIV/AIDS are few in Ethiopia. Hence, the present study was undertaken to investigate the concentration of serum zinc among sex and age matched pre ART and on ART adults. Methods: A cross-sectional study was conducted among 150 people living with HIV/AIDS (75 pre -ART and 75 on -ART) adults. Concentrations of zinc from serum were measured using fully automated flame atomic absorption spectrophotometer. $\mathrm{CD}^{+}$T-cell count, $\mathrm{CD}^{+}$T-cell count, hemoglobin determination, and Body Mass Index (BMI) were performed to evaluate the clinical status of study participants. Results: Serum zinc deficiencies were observed in 46 (30.7\%) study participants. In multivariate logistic regression analysis, pre-ART study participants were nearly four times more likely at risk of serum zinc deficiency than on-ART study participants ( $\mathrm{AOR}=3.56,95 \% \mathrm{CI}=1.52$ to 8.32 ). Similarly, the odds of being serum zinc deficient were three times more in undernourished study participants than nourished study participants ( $\mathrm{AOR}=2.61,95 \% \mathrm{CI}=1.02$ to 6.67 ). Conclusion: A relatively high percentage of study participants had serum zinc deficiency. Early evaluation of serum zinc deficiency and zinc supplementation along with anti-retroviral treatment should be considered for pre-ART and under nourished adult people living with HIV/AIDS.
\end{abstract}

Keywords: Antiretroviral Therapy, Bahir Dar, HIV/AIDS, Serum Zinc Deficiency

\section{Introduction}

Back ground: - Trace elements are micronutrients that have recent attention as potential interventions to delay HIV progression [1]. Among several trace elements, zinc is an antioxidant micronutrient that have been playing a very significant role in maintaining immune function and neutralizing the reactive oxygen intermediates produced by activated macrophages and neutrophils in their response to microorganisms [2-5].

Serum and plasma measurements of trace elements, which are indicators of body stores, have shown that deficiencies are common among people living with HIV/AIDS (PLWHA). The deficiency of antioxidant trace elements in PLWHA is due to the excessive release of pro-oxidants and cytokines leading to increased utilization of antioxidants like zinc [6]. The depletion of trace elements may also occur through increased metabolic requirements, enhanced excretion, and intestinal mal-absorption [7]. This can result in an imbalance between pro-oxidants and antioxidants which may lead to increased oxidative stress which in turn may cause further damage to human cells, proteins and enzymes, thus accelerating HIV replication and mortality of the patient [8].

In HIV infection, low concentrations of serum micronutrients were frequently reported in the pre -ART era 
and were linked with worsened HIV status and mortality [6]. Studies in the Nutrition for Healthy Living (NFHL) cohort suggest that extremes in higher micronutrient intake are increasingly more common in patients receiving ART. This trend is resulting in the transformation of serum micronutrient profiles in this population [9].

Studies investigating trace elements status of HIV infected populations have been done in developed countries and showed low serum or plasma levels $[10,11]$. However, limited studies have been done in developing countries [12, 13]. No studies have been found in Ethiopia particularly in the study area on serum Zn deficiency status among on-ART and pre-ART PLWHA. Therefore, the present study aimed to assess the deficiency of serum zinc in relation to clinical status among adults who were on-ART and pre-ART at Felege Hiwot Referral Hospital in Bahir Dar, Northwest Ethiopia.

\section{Methodology}

\subsection{Study Design and Participants}

Facility based cross-sectional study was conducted consecutively on adult people living with HIV/AIDS at ART care clinic in Felege Hiwot Referral Hospital, Bahir Dar, North West Ethiopia. Ethical approval was obtained from Bahir Dar University and informed consent was obtained from the study participants.

\subsection{Blood Collection and Serum Separation}

After an overnight fasting, ten milliliter of blood sample was drawn from each participant using a vacuum tube system. From this amount $5 \mathrm{ml}$ of blood was dispensed and mixed with a labeled Ethylene Diamine Tetra Acetic Acid (EDTA) coated test tube for CD4/CD8 T-cell count and haemoglobin determination. The remaining $5 \mathrm{ml}$ of blood was collected with labeled plain test tube and immediately after 30 minutes of collection sera were separated by centrifugation at 3000 revolution per minute for 5 minutes then aliquot into labeled nunc tube. The aliquot was protected from light, and stored at $-70^{\circ} \mathrm{C}$ until analysis for serum trace elements.

\subsection{Immuno-Hematological Analysis}

CD4+ T-cell and CD8+ T-cell count were analyzed on FACScan flow cytometer (Becton Dickinson Immunocytometry Systems, San Jose, California) with the method as described by Tsegaye, et al. [14]. Hemoglobin was determined by using HemoCue 301 analyzer (Sweden) following the procedure described by Gillet et al [15].

For this study, normal reference range for CD $8+$ T-cell count for male and female were $318-1891 / \mu 1$ and 273-1418/ $\mu 1$ respectively, CD4:CD8 T-cell ratio for male and female were 0.4-2.1 and 0.6-2.7 respectively and anemic based on hemoglobin value for male and female were $<14 \mathrm{gm} / \mathrm{dl}$ and $<13 \mathrm{gm} / \mathrm{dl}$ respectively, all references were based on the immuno-hematological reference ranges for adult Ethiopians [14]. Based on CD4 T-cell count there are four proposed immunological HIV-related immunodeficiency classification outlines; no significant immunodeficiency $(\geq 500$ CD4 $\mathrm{T}$ cells $/ \mu \mathrm{l})$, mild immunodeficiency (350-499 CD4 T-cells / $\mu \mathrm{l})$, advanced immunodeficiency (200-349 CD4 T-cells / $\mu$ l) and severe immunodeficiency ( $<200$ CD4 T-cells $/ \mu \mathrm{l})[16]$.

All immuno-hematological analytical procedure was done at Felege Hiwot Referral Hospital.

\subsection{Biochemical Analyses}

The frozen serum samples were kept on dry ice and transported to Addis Ababa. Serum concentration of $\mathrm{Zn}$ was measured using fully automated flame atomic absorption spectrophotometer version 2006 (PG-990, London, England), following the procedure described by Mahajan et al. [17]. The measurements were done at JIJE Analytical Testing Service Laboratory (JATSL), Addis Ababa, Ethiopia. For this study, deficiency of serum zinc was defined at their serum levels less than $70 \mu \mathrm{g} / \mathrm{dl}$ [18].

\subsection{Anthropometric Measurements}

Anthropometric measurements (Height, weight, upper mid arm, waist and hip circumference) were done in triplicate and the mean value was recorded. Weight and height were measured with minimal clothing and without shoe to the nearest $0.1 \mathrm{~kg}$ and $1 \mathrm{~mm}$ respectively. BMI $\left(\mathrm{kg} / \mathrm{m}^{2}\right)$ was calculated for each participant. A cut off point less than 18.5 was used to define under nourished and a BMI of 25 or above indicate overweight or obesity [19].

\subsection{Data Analysis}

Information recorded in the questionnaire and laboratory was entered and analyzed using SPSS (Chicago, IL, USA) software, version 16 . The descriptive data were analyzed with means and standard deviations, frequency counts and percentages. Cross tabulations were carried out to compare frequencies of individual characteristics and logistic regression analysis was applied to test the strength of the association between independent and dependent variables. Any variable with a significant bivariate test at $\mathrm{P}$-value less than or equal to 0.2 was selected as a candidate for the multivariate analysis and backward step wise elimination model was applied [20]. Values were considered significant when $\mathrm{P}$-value is less than 0.05 .

\subsection{Data Quality Assurance}

Standard questionnaire was used and data was collected by trained clinician with regular monitoring by the investigator. Laboratory internal quality control was monitored during the procedure and all the measurements were carried out by the same team. All glassware and bottles for blood collection, separation of serum and further analysis were used after soaked and then rinsed them with $10 \%$ nitric acid and de-ionized water respectively. Contamination tests for $\mathrm{Zn}$ were carried out in between 10 participants. Training 
and procedures was given for data collectors.

\subsection{Ethical Considerations}

Before data collection, ethical approval was obtained from the board of Bahir Dar University. Permission was obtained from Amhara Regional Health Bureau and from Felege Hiwot Referral Hospital administrators. Written informed consent was obtained from the study participants after the purpose of the study was explained. Participants were informed that all the data obtained from them would be kept confidential using codes instead of any personal identifiers

\section{Result}

\subsection{Socio-Demographic and Clinical Characteristics of Study Participants}

Table 1. Socio-demographic and clinical characteristics of study participants in Felege Hiwot Referral Hospital, Bahir Dar from January to February, 2013.

\begin{tabular}{|c|c|c|c|}
\hline \multirow[t]{2}{*}{ Characteristics } & \multicolumn{2}{|c|}{$\begin{array}{l}\text { ART status } \\
\text { N (\%) } \\
\end{array}$} & \multirow{2}{*}{$\begin{array}{l}\text { Total } \\
\text { N }(\%)\end{array}$} \\
\hline & Pre-ART & On-ART & \\
\hline \multicolumn{4}{|l|}{ Sex } \\
\hline Male & $26(50.0)$ & $26(50.0)$ & $52(34.7)$ \\
\hline Female & $49(50.0)$ & $49(50.0)$ & $98(65.3)$ \\
\hline \multicolumn{4}{|l|}{ Age } \\
\hline $18-28$ & $20(55.6)$ & $16(44.4)$ & $36(24.0)$ \\
\hline $29-39$ & $34(50.7)$ & $33(49.3)$ & $67(44.7)$ \\
\hline $40-50$ & $16(45.7)$ & $19(54.3)$ & $35(23.3)$ \\
\hline $51-60$ & $5(41.7)$ & $7(58.3)$ & $12(8.0)$ \\
\hline \multicolumn{4}{|l|}{ Residence } \\
\hline Urban & $56(45.9)$ & $66(54.1)$ & $122(81.3)$ \\
\hline Rural & $19(67.9)$ & $9(32.1)$ & $28(18.7)$ \\
\hline \multicolumn{4}{|l|}{ Educational status } \\
\hline Illiterate & $34(61.8)$ & $21(38.2)$ & $55(36.7)$ \\
\hline Primary & $16(50.0)$ & $16(50.0)$ & $32(21.3)$ \\
\hline Secondary & $19(41.3)$ & $27(58.7)$ & $46(30.7)$ \\
\hline Tertiary & $6(35.3)$ & $11(64.7)$ & $17(11.3)$ \\
\hline \multicolumn{4}{|l|}{ Occupational status } \\
\hline Unemployed & $12(52.2)$ & $11(47.8)$ & $23(15.3)$ \\
\hline Casual Laborer & $9(56.2)$ & $7(43.8)$ & $16(10.7)$ \\
\hline Farmer & $8(100.0)$ & $0(0.0)$ & $8(5.3)$ \\
\hline Student & $2(50.0)$ & $2(50.0)$ & $4(2.7)$ \\
\hline Private employee & $30(46.9)$ & $34(53.1)$ & $64(42.7)$ \\
\hline Government employee & $14(40.0)$ & $21(60.0)$ & $35(23.3)$ \\
\hline \multicolumn{4}{|l|}{ CD4+T-cell count/ $\mu \mathrm{l}$} \\
\hline$>500$ & $18(50.0)$ & $18(50.0)$ & $36(24.0)$ \\
\hline $350-500$ & $20(52.6)$ & $18(47.4)$ & $38(25.3)$ \\
\hline $200-349$ & $18(45.0)$ & $22(55.0)$ & $40(26.7)$ \\
\hline$<200$ & $19(52.8)$ & $17(47.2)$ & $36(24.0)$ \\
\hline \multicolumn{4}{|c|}{ CD4:CD8 T-cell count ratio } \\
\hline Normal & $12(35.3)$ & $22(64.7)$ & $34(22.7)$ \\
\hline Abnormal & $63(54.3)$ & $53(45.7)$ & $116(77.3)$ \\
\hline \multicolumn{4}{|l|}{ BMI (Body Mass Index) } \\
\hline Nourished & $58(50.4)$ & $57(49.6)$ & $115(76.6)$ \\
\hline Under nourished & $13(46.4)$ & $15(53.6)$ & $28(18.7)$ \\
\hline Obese & $4(57.1)$ & $3(42.9)$ & $7(4.7)$ \\
\hline \multicolumn{4}{|l|}{ Hgb (Hemoglobin) } \\
\hline Normal & $54(47.8)$ & $59(52.2)$ & $113(75.3)$ \\
\hline Anemic & $21(56.8)$ & $16(43.2)$ & $37(24.7)$ \\
\hline
\end{tabular}

From a total number of study participants, $98(65.3 \%)$ were females from these $49(50 \%)$ were pre-ART. Mean age of study participants were $36 \pm 8.8$ years ranging from 18 to 60 years old. According to the anti-retroviral therapy status, $75(50 \%)$ of the study participants had started ART more than a year ago. Regarding to the BMI analysis, 28 (18.7\%) of the study participants had a BMI of lower than 18.5 and showed signs of under nourishment from these 15 (53.6\%) were on-ART (Table 1)

\subsection{Distributions of Low Serum Zinc Concentration Based on Socio-Demographic and Clinical Characteristics}

The overall mean value of serum zinc concentration of study participants was $88.7 \pm 31.84$ ranging from 19 to 269 $\mu \mathrm{g} / \mathrm{dl}$. Based on cutoff points of low serum zinc concentration $(<70 \mu \mathrm{g} / \mathrm{dl})$, it was found that $46(30.7 \%)$ participants had low serum zinc concentration.

Higher serum zinc concentration was found in female than male study participants with the mean of $90.7 \pm 32.7$ and $84.9 \pm 30 \mu \mathrm{g} / \mathrm{dl}$ respectively. According to the age category, most proportion 27/67 (40.3\%) of study participants with the age of 29-39 years old had low serum zinc concentration. Low serum zinc concentration was found in $23 / 55(41.8 \%)$ of illiterate study participants while $4 / 17(23.5 \%)$ was found in tertiary level educated.

The mean serum zinc concentration of study participants who had a CD4+ T-cell count $>500$ cells/ $\mu$ l was higher $96.08 \pm 32.8 \mu \mathrm{g} / \mathrm{dl}$ than in those study participants who had a CD4+ T-cell count $<200$ cells $/ \mu 1$ with the mean of $85.06 \pm 29$ $\mu \mathrm{g} / \mathrm{dl}$. Low serum zinc concentration was observed in $11 / 36$ (30.6\%) of those study participants who had a CD4+ T-cell count $<200$ cells $/ \mu$ from these $9 / 11(81.8 \%)$ were found in pre-ART while low serum zinc in a CD4+ T-cell count $>500$ cells/ $\mu$ l was $9 / 36(25 \%)$ from these $7 / 9(77.8 \%)$ were from pre-ART.

The mean serum zinc concentration of study participants who had a normal CD4:CD8+T-cell count ratio was higher $(95.76 \pm 32.03 \mu \mathrm{g} / \mathrm{dl})$ than in an abnormal CD4:CD8+T-cell count ratio with the mean of $86.63 \pm 31.62 \mu \mathrm{g} / \mathrm{dl}$. Low serum zinc concentration was found in $38 / 116(32.8 \%)$ of study participants who had abnormal CD4:CD8+T-cell count ratio from these $31 / 38(81.6 \%)$ were per-ART while Low serum zinc concentration of normal CD4:CD8+T-cell count ratio was found in $8 / 34(23.5 \%)$ from these $6 / 8(75.0 \%)$ were on-ART.

Low serum zinc concentration was observed in $15 / 37(40.5 \%)$ of anemic study participants, of this $12 / 15$ $(80.0 \%)$ were pre-ART. The mean serum zinc concentration of study participants with hemoglobin value anemic were lower (77.73 \pm 24.99$)$ than those study participants with normal hemoglobin value $(92.29 \pm 33.09)$ (Table 2$)$.

On-ART study participants were significantly higher mean serum zinc concentration $(98.43 \pm 32.47 \mu \mathrm{g} / \mathrm{dl})$ compared to pre-ART $(78.97 \pm 28.20 \mu \mathrm{g} / \mathrm{dl})$. But proportion of low serum zinc concentration was higher in 33/75 (44\%) pre-ART study participants than on-ART in $13 / 75(17.3 \%)$ (Figure1). 
Table 2. The distribution of serum zinc concentration by socio-demographic and clinical characteristics in Felege Hiwot Hospital, Bahir Dar from January to February, 2013.

\begin{tabular}{|c|c|c|}
\hline \multirow{2}{*}{ Characteristics } & \multicolumn{2}{|c|}{ Serum zinc status N (\%) } \\
\hline & $\geq 70 \mu \mathrm{g} / \mathrm{dl}$ & $<70 \mu \mathrm{g} / \mathrm{dl}$ \\
\hline \multicolumn{3}{|l|}{ Sex } \\
\hline Male & $35(67.3)$ & $17(32.7)$ \\
\hline Female & $69(70.4)$ & $29(29.6)$ \\
\hline \multicolumn{3}{|l|}{ Age } \\
\hline $18-28$ & $29(80.6)$ & $7(19.4)$ \\
\hline $29-39$ & $40(59.7)$ & $27(40.3)$ \\
\hline $40-50$ & $25(71.4)$ & $10(28.6)$ \\
\hline $51-60$ & $10(83.3)$ & $2(16.7)$ \\
\hline \multicolumn{3}{|l|}{ Residence } \\
\hline Urban & $84(68.9)$ & $38(31.1)$ \\
\hline Rural & $20(71.4)$ & $8(28.6)$ \\
\hline \multicolumn{3}{|l|}{ Educational status } \\
\hline Illiterate & $32(58.2)$ & $23(41.8)$ \\
\hline Primary & $25(78.1)$ & $7(21.9)$ \\
\hline Secondary & $34(73.9)$ & $12(26.1)$ \\
\hline Tertiary & $13(76.5)$ & $4(23.5)$ \\
\hline \multicolumn{3}{|l|}{ Occupational status } \\
\hline Unemployed & $17(73.9)$ & $6(26.1)$ \\
\hline Casual Laborer & $9(56.2)$ & $7(43.8)$ \\
\hline Farmer & $2(25.0)$ & $6(75.0)$ \\
\hline Student & $2(50.0)$ & $2(50.0)$ \\
\hline Private employee & $47(73.4)$ & $17(26.6)$ \\
\hline Government employee & $27(77.1)$ & $8(22.9)$ \\
\hline \multicolumn{3}{|l|}{ Physical exercise } \\
\hline No & $66(65.3)$ & $35(34.7)$ \\
\hline Yes & $38(77.6)$ & $11(22.4)$ \\
\hline \multicolumn{3}{|l|}{ ART status } \\
\hline Pre ART & $42(56.00)$ & $33(44.00)$ \\
\hline On ART & $62(82.70)$ & $13(17.30)$ \\
\hline \multicolumn{3}{|l|}{ CD4 T-cell count/ $\mu \mathrm{l}$} \\
\hline$>500$ & $27(75.00)$ & $9(25.00)$ \\
\hline $350-500$ & $22(57.90)$ & $16(42.10)$ \\
\hline $200-349$ & $30(75.00)$ & $10(25.00)$ \\
\hline$<200$ & $25(69.40)$ & $11(30.60)$ \\
\hline \multicolumn{3}{|c|}{ CD4:CD8 T-cell count ratio } \\
\hline Normal & $26(76.50)$ & $8(23.50)$ \\
\hline Abnormal & $78(67.20)$ & $38(32.80)$ \\
\hline \multicolumn{3}{|l|}{$\mathrm{Hgb}$} \\
\hline Normal & $82(72.60)$ & $31(27.40)$ \\
\hline Anemic & $22(59.50)$ & $15(40.50)$ \\
\hline \multicolumn{3}{|l|}{ BMI } \\
\hline Nourished & $84(73.00)$ & $31(27.00)$ \\
\hline Malnourished & $16(57.10)$ & $12(42.90)$ \\
\hline Obese & $4(57.10)$ & $3(42.90)$ \\
\hline
\end{tabular}

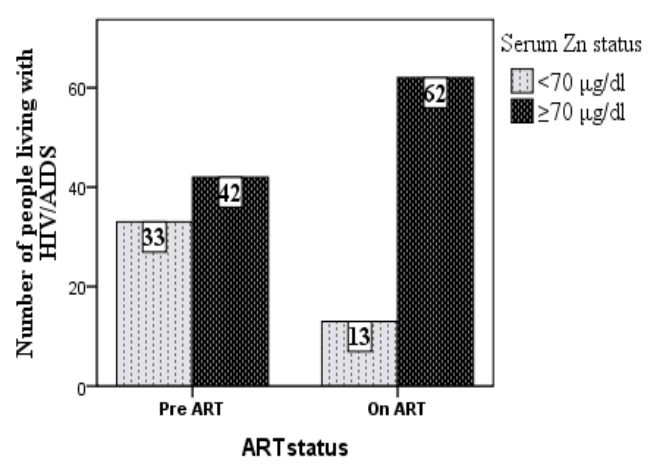

Figure 1. The distribution of low serum zinc concentration with reference to ART status of study participants in Felege Hiwot Referral Hospital, Bahir Dar, Ethiopia from January to February, $2013(n=150)$.
The overall percentage of low serum zinc concentration among combinations ARV drugs were found 13/75 (17.3\%) from these the majority $5 / 13(38.4 \%)$ was found in participants who were receiving AZT-3TC-NVP (Figure 2).

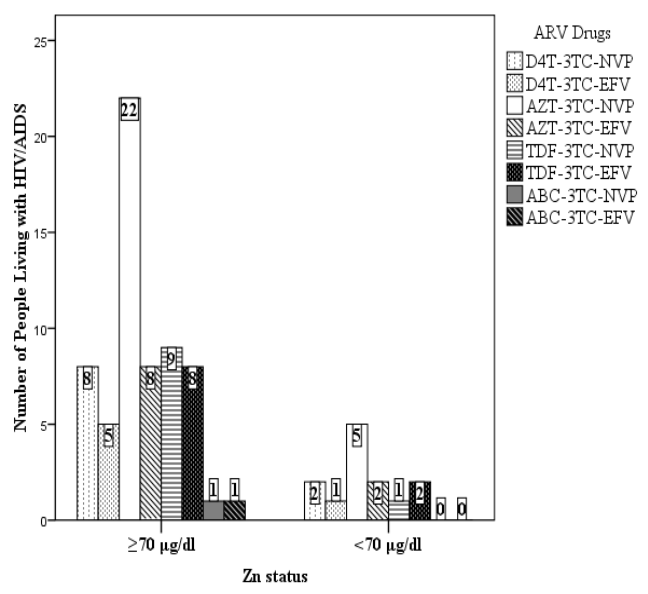

Figure 2. The distribution of low serum zinc concentration with reference to ARV drugs of study participants in Felege Hiwot Referral Hospital, Bahir Dar from January to February, 2013 ( $n=150)$.

Based on the BMI of study participants, 12/28 (42.9\%) of low serum zinc concentration were observed in under nourished study participants from these 8/12 (66.6\%) were pre-ART. Low serum zinc concentration was found also in $31 / 115(27 \%)$ of nourished study participants, of these $22 / 31$ (70.9\%) were pre-ART. The mean serum zinc concentration of study participants with a BMI of under nourished were lower $78.46 \pm 22.55$ than in those study participants with a BMI of well nourished $91.69 \pm 33.04$ (Figure 3).

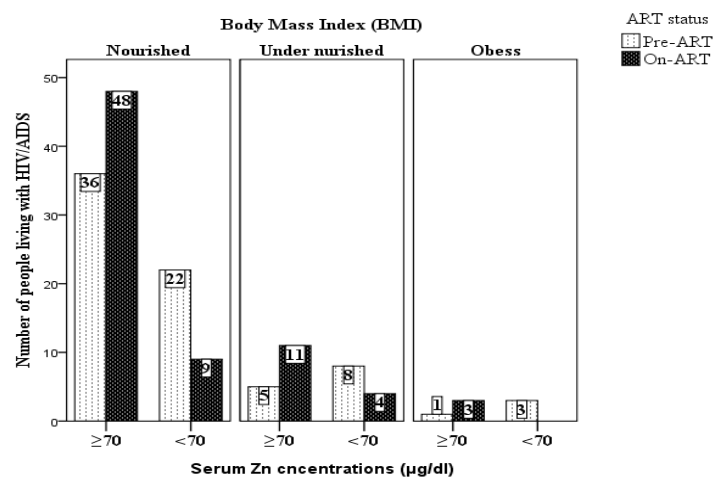

Figure 3. The distribution of low serum zinc concentration with reference to Body Mass Index (BMI) and ART status of study participants in Felege Hiwot Referral Hospital, Bahir Dar from January to February, $2013(n=150)$.

\subsection{Logistic Regression Analysis of Variables Associated With Low Serum Zinc Concentration}

Two factors were the strongest predictor of low serum zinc concentration. The odds ratio of being low serum zinc concentration by pre-ART study participants were more likely at risk of low serum zinc concentration than those on-ART study participants $(\mathrm{AOR}=3.56,95 \% \mathrm{CI}=1.52-8.33$ $\mathrm{p}=0.003$ ). Similarly, the odds ratio of being low serum zinc 
concentration by under nourished study participants were more likely at risk of low serum zinc concentration than those nourished study participants $(\mathrm{AOR}=2.61,95 \%$ $\mathrm{CI}=1.02-6.67 \mathrm{p}=0.046)$. Regression analyses of age, educational status, occupational status, CD4 T cell count/ $\mu \mathrm{l}$ and $\mathrm{Hgb}$ (hemoglobin) as independent variables and low serum zinc concentration as dependent variable did not show any significant association at 95\% CI (Table 3).

Table 3. Logistic regression analysis of selected socio-demographic and clinical variables associated with the distribution of low serum zinc concentration in Felege Hiwot Referral Hospital, Bahir Dar from January to February, 2013) (N=150).

\begin{tabular}{|c|c|c|c|c|c|}
\hline \multirow[t]{2}{*}{ Characteristics } & \multicolumn{2}{|c|}{ Serum Zinc status N (\%) } & \multicolumn{2}{|l|}{ OR[95\% CI] } & \multirow[t]{2}{*}{ P-value } \\
\hline & $\geq 70 \mu \mathrm{g} / \mathrm{dl}$ & $<70 \mu \mathrm{g} / \mathrm{dl}$ & COR & AOR & \\
\hline \multicolumn{6}{|l|}{ Age } \\
\hline $18-28$ & $29(80.6)$ & $7(19.4)$ & $1.00 *$ & $1.00 *$ & \\
\hline $29-39$ & $40(59.7)$ & $27(40.3)$ & $2.79[1.07-7.29]$ & $3.52[1.13-10.91]$ & 0.029 \\
\hline $40-50$ & $25(71.4)$ & $10(28.6)$ & $1.66[0.55-4.99]$ & $2.11[0.60-7.38]$ & 0.241 \\
\hline $51-60$ & $10(83.3)$ & $2(16.7)$ & $0.83[0.15-4.66]$ & $1.13[0.18-7.13]$ & 0.891 \\
\hline \multicolumn{6}{|l|}{ Educational status } \\
\hline Illiterate & $32(58.2)$ & $23(41.8)$ & $2.33[0.67-8.09]$ & $1.32[0.201-8.74]$ & 0.77 \\
\hline Primary & $25(78.1)$ & $7(21.9)$ & $0.91[0.22-3.69]$ & $0.51[0.067-3.91]$ & 0.52 \\
\hline Secondary & $34(73.9)$ & $12(26.1)$ & $1.15[0.313-4.21]$ & $0.81[0.156-4.19]$ & 0.801 \\
\hline Tertiary & $13(76.5)$ & $4(23.5)$ & $1.00 *$ & $1.00 *$ & \\
\hline \multicolumn{6}{|l|}{ Occupation } \\
\hline Unemployed & $17(73.9)$ & $6(26.1)$ & $1.19[0.35-4.03]$ & $1.12[0.24-5.27]$ & 0.886 \\
\hline Causal laborer & $9(56.2)$ & $7(43.8)$ & $2.62[0.74-9.29]$ & $2.16[0.47-9.94]$ & 0.324 \\
\hline Farmer & $2(25.0)$ & $6(75.0)$ & $10.12[1.70-60.29]$ & $6.31[0.72-55.55]$ & 0.097 \\
\hline Student & $2(50.0)$ & $2(50.0)$ & $3.37[0.41-27.92]$ & $7.84[0.69-89.07]$ & 0.097 \\
\hline Private employed & $47(73.4)$ & $17(26.6)$ & $1.22[0.46-3.20]$ & $1.19[0.38-3.73]$ & 0.767 \\
\hline Government employed & $27(77.1)$ & $8(22.9)$ & $1.00 *$ & $1.00 *$ & \\
\hline \multicolumn{6}{|l|}{ ART status } \\
\hline Pre-ART & $42(56.0)$ & $33(44.0)$ & $3.75[1.77-7.95] \approx$ & $3.56[1.52-8.33]$ & $0.003 \Phi$ \\
\hline On-ART & $62(82.7)$ & $13(17.3)$ & $1.00 *$ & $1.00 *$ & \\
\hline \multicolumn{6}{|l|}{ CD4 T-cell count/ $\mu \mathrm{l}$} \\
\hline$>500$ & $27(75.0)$ & $9(25.0)$ & $1.00 *$ & $1.00 *$ & \\
\hline $350-500$ & $22(57.9)$ & $16(42.1)$ & $2.18[0.81-5.88]$ & $3.18[0.88-11.41]$ & 0.076 \\
\hline $200-349$ & $30(75.0)$ & $10(25.0)$ & $1.00[0.35-2.83]$ & $1.64[0.42-6.36]$ & 0.477 \\
\hline$<200$ & $25(69.4)$ & $11(30.6)$ & $1.32[0.47-3.72]$ & $1.17[0.32-4.24]$ & 0.813 \\
\hline \multicolumn{6}{|l|}{ BMI } \\
\hline Nourished & $84(73.0)$ & $31(27.0)$ & $1.00 *$ & $1.00 *$ & \\
\hline Under nourished & $16(57.1)$ & $12(42.9)$ & $2.03[0.86-4.77]$ & $2.61[1.02-6.67]$ & $0.046 \Phi$ \\
\hline Obese & $4(57.1)$ & $3(42.9)$ & $2.03[0.43-9.60]$ & $1.98[0.37-10.64]$ & 0.425 \\
\hline \multicolumn{6}{|l|}{ Hemoglobin (Hgb) } \\
\hline Normal & $82(72.6)$ & $31(27.4)$ & $1.00 *$ & $1.00 *$ & \\
\hline Anemic & $22(59.5)$ & $15(40.5)$ & $1.80[0.83-3.92]$ & $2.11[0.82-5.40]$ & 0.119 \\
\hline
\end{tabular}

*-reference category for independent variable, $\mho$-statistically significant at COR, $\Phi$ - statistically significant at AOR (p $\leq 0.05$ )

\section{Discussion}

Serum and plasma measurements of trace elements, which are indicators of body stores, have shown that deficiencies are common among HIV infected persons. The depletion of trace elements may occur through increased metabolic requirements, enhanced excretion, and intestinal mal-absorption [7]. The current study was hypothesized that significant lower serums zinc concentration and higher HIV disease progression among pre-ART than on-ART PLWHA.

The overall low serum zinc $(<70 \mu \mathrm{g} / \mathrm{dL})$ concentration of the current study was $30.70 \%$ which is higher than the study conducted in Argentina 23\% [21]; it was lower than previous findings in Iran 65\% [22], in USA, Boston $42 \%$ [11], South Africa 45\% [23], in Addis Ababa 53.6\% [24] Gondar $69.7 \%$ [25]. Selecting different cut off points for determining low serum zinc concentration could be a reason for this variation. Other reasons could be variation in study area, commencement of ART and intake of dietary item and frequency.

In the current study, the proportion of serum zinc deficiency was higher (44\%) in pre-ART study participants than $17.3 \%$ in on-ART. In accordance to the present study a study in Uganda serum zinc deficiency was higher in 59.6\% of pre-ART than in $29.5 \%$ of on-ART [26]. In contrast to this, a study in Germany showed that a similar distribution of low serum zinc concentration was identified in $25 \%$ and $22 \%$ of on-ART and pre-ART respectively [10]. Similarly a study in India showed that low zinc concentration was found pre-ART and on-ART which resulted in a 50\% deficiency in both groups [27].

In the current study, the mean serum zinc concentration of study participants who had a CD4+ T-cell count $<200$ cells $/ \mu \mathrm{l} \quad$ was lower $\quad(85.06 \pm 29.00 \mu \mathrm{g} / \mathrm{dl}) \quad$ than $96.08 \pm 32.804 \mu \mathrm{g} / \mathrm{dl}$ in those study participants who had a CD4+ T-cell count $>500$ cells $/ \mu \mathrm{l}$. This finding is in accordance with the study in India with the mean $83.12 \pm 12.29 \mu \mathrm{g} / \mathrm{dl}$ and $106.68 \pm 4.11 \mu \mathrm{g} / \mathrm{dl}$ of CD4 T-cells 
count $<200 / \mu 1$ and CD4 cell count $>500$ cell/ $\mu 1$ respectively [29]. In the current study, $30.6 \%$ of low serum zinc concentration was observed in those study participants who had a CD4+ T-cell count $<200$ cells $/ \mu$ g while $25 \%$ of low serum zinc concentration were observed in those group who had a CD4+ T-cell count $>500$ cells $/ \mu$ l. This finding is in agreement with a study in India which revealed that a lower serum $\mathrm{Zn}$ level was found in patients with CD4 cells count $<$ $200 / \mu$ l than with $>500$ cells $/ \mu 1$ [28].

In the present study, low serum zinc concentration was higher in (42.9\%) of under nourished study participants than $27 \%$ in nourished study participants. This study was in agreement with a study in Iran found that higher $(41.7 \%)$ in under nourished study participants than $33.6 \%$ in nourished study participants [22].

In logistic regression analysis, the finding of this study revealed that, pre-ART study participants were more likely at risk of low serum zinc concentration than those on-ART study participants $(\mathrm{AOR}=3.56,95 \% \mathrm{CI}=1.52-8.33 \mathrm{p}=$ 0.003). The differences might be due to the role of combination therapy with ARVs that reduces viral replication, pro-oxidants and cytokines. This study is in accordance with a study in Uganda which showed that pre-ART study participants were more likely at risk of low serum zinc concentration than those on-ART study participants $(\mathrm{AOR}=3.7,95 \% \mathrm{CI}=1.8$ - 7.7) [26].

In the current study CD4+ $\mathrm{T}$ cell count had no association with zinc status. This finding is similar to what was reported in India [26]. BMI status was one of clinical determinant for low serum zinc concentration, under nourished study participants were significantly and more likely at a risk of low serum zinc concentration than nourished study participants $(\mathrm{AOR}=2.61,95 \% \mathrm{CI}=1.02-6.67, \mathrm{p}=0.046)$. This association was also reported in previous studies in South Africa $(\mathrm{AOR}=1.19,95 \% \mathrm{CI}=1.09-1.30, \mathrm{p}<0.05)$ [23].

Most of the socio-demographic features in the present study were not statistically significant as predictors for the deficiency of serum zinc among people living with HIV/AIDS at 95\% CI. Demographic variables such as sex, residence location, marital status, monthly income and level of education were not implicated as determinants for serum zinc deficiency among the study participants. This similar finding has been reported by Visser et al., (2003), Diaz Romero et al., (2002) [23,29].

\section{Conclusion}

The percentages of overall serum $\mathrm{Zn}$ deficiency indicated that PLWHA are likely to have abnormal micronutrient concentrations. Being HIV positive may lead to the depletion of $\mathrm{Zn}$ serum concentrations which are in turn associated with disease progression.

ART status of the study participants was identified as one of the clinical factors that had a significant association with low serum $\mathrm{Zn}$ concentrations as was indicated by the multiple logistic regression analysis. Those PLWHA and are on ART are less likely to have low serum $\mathrm{Zn}$ concentration than those who are not on ART. Body mass index were also found to be important predictors of low serum $\mathrm{Zn}$ concentration. Those PLWHA who are undernourished were likely to have low serum $\mathrm{Zn}$ concentration than those who are nourished.

Based on the major findings of the study, the following recommendations were made. Early evaluation of biochemical analyses for serum zinc deficiency should be carried out. Regular health education and counseling about maintain adequate healthy diet should be applied to PLWHA especially for those pre ART PLWHA. Providing appropriate mineral supplementation along with anti-retroviral treatment may be required especially for those who are in pre-ART and under nourished groups living with HIV/AIDS. To determine the other causes of serum zinc deficiency, a cohort study should be conducted among people living with HIV/AIDS.

\section{Acknowledgements}

We wish to thank people living with HIV/AIDS who participated in the study, without them, I would have not been able to bring our work to a successful completion. We sincerely thank Bahir Dar University, college of science, department of biology for funding the research work. We would like to express our appreciation to all staff of JIJE analytical testing service laboratory and Felege Hiwot referral hospital for their cooperation during data collection.

\section{References}

[1] Marston, B., De. Cock, K.M.(2004) Multivitamins, Nutrition, and Antiretroviral Therapy for HIV Disease in Africa. N. Eng. J. Med. 351: 78-80.

[2] Caddell, J.L. (1996). A review of evidence for a role of magnesium and possible copper deficiency in necrotizing enterocolitis. Magn. Res. 9: 55-66.

[3] Alarcon, O.M, Reinosa-fulter, J., Silva, T.M, Angarita, C., Teran, E., Nava, M., Solano, P., Agostineki, M. (1997). Serum level of $\mathrm{Zn}, \mathrm{Cu}$ and $\mathrm{Fe}$ in healthy school children residing in Merida, Venezuela. Arch. Latinoam Nutr. 47: 118-122.

[4] Lindahl, M., Leanderson, P., Tagesson, C. (1998). Novel aspects of metal fume fever. Zinc stimulates oxygen radicals' formation in human neutrophills. Human Exp. Toxicol. 17: 105-110.

[5] Prasad, A. (2000). Effect of zinc deficiency on immune function: J Trace Elements Exp Med.13:1-20

[6] Tang, A.M., Graham, N.M.H., Saah, A.J.(1996). Effects of micronutrient intake on survival in human immunodeficiency virus type 1 infection. Am J Epidemiol. 143: 1244-56.

[7] Fawzi, W.(2003 Micronutrients and Human Immunodeficiency Virus Type 1 Disease Progression among Adults and Children. Clin. Infect. Dis. 37: S112-116. 
[8] Friis, H. and Michaelsen, K.(1998), Micronutrients in HIV infection: a review. European J. Clin. Nutr. 52: 157-163

[9] Jones, C.Y., Tang, A.M., Forrester, J.E., et al.(2006) Micronutrient levels and HIV disease status in HIV-infected patients on Antiretroviral Therapy in the Nutrition for Healthy Living cohort. J Acquir Immune Defic Syndr. 43: 475-82.

[10] Wellinghausen, N., Kern, W.V., Jochle, W., Kern, P.(2000). Zinc serum concentration in human immunodeficiency virus-infected patients in relation to immunological status. Biol Elem Trace Res. 73: 139-49.

[11] Falcone, E., Mangili, A., Tang ,M., Jones ,Y., Woods , N., Polak .F., and Awanke ,C.(2010) Micronutrient concentrations and subclinical atherosclerosis in adults. Am J Clin Nutr. 91: 1213-9.

[12] Semba, R.D. and Tang, A.M.(1999) Micronutrients and the pathogenesis of human immunodeficiency virus infection. British Journal of Nutrition. 81: 181-189.

[13] Kassu, A., Yabutani. T., Mulu, A., Tessema. B., Ota, F.(2008) Serum zinc, copper, selenium, calcium, and magnesium levels in pregnant and non-pregnant women in Gondar, Northwest Ethiopia. Biological Trace Element Research. 122(2):97-106

[14] Tsegaye, A., Messele, T., Tilahun, T., Hailu, E., Sahlu, T., Doorly, R., Fontanet, A., Rinke de Wit, T. F. (1999). Immunohematological Reference Ranges for Adult Ethiopians. American Society for Microbiology. 410-414

[15] Gillet, P., Boel, L., Jacobs, J. (2009). Practical notes on tropical hematology, Postgraduate in tropical medicine and international health module 2 clinical and biomedical sciences of tropical diseases.1-77

[16] WHO. (2006). WHO case definitions of HIV for surveillance and revised clinical staging and immunological classification of HIV-related disease in adults and children. HIV/AIDS Programme, 20 Avenue Appia, 1211 Geneva 27, Switzerland.

[17] Mahajan, R., Walia, T., Sumanjit. (2005). Trace Element Estimation, Methods \& Clinical Context: J Health Allied Scs; $1: 1$

[18] Duh, S.H., Cook, J.D. (2005). Laboratory reference range values. APP 96-111

[19] WHO. (1995). Physical Status: The use and interpretation of anthropometry; report of a WHO expert committee. Geneva.
[20] Bursac, Z., Gauss, C. H., Williams, D. K., Hosmer, D. W. 2008. Purposeful selection of variables in logistic regression: Biology and Medicine 2008, 3:17

[21] Marcela, S., Susana, F. and Nora, H. S. (2007) Nutritional status in patients with HIV infection and AIDS. British Journal of Nutrition. 98: S140-S143.

[22] Khalili, H., Soudbakhsh, A., Hajiabdolbaghi, M., Dashti-Khavidaki, S., Poorzare, A., Saeedi, A.A. and Sharififar, R.(2008) Nutritional status and serum zinc and selenium levels in Iranian HIV infected individuals . BMC Infectious Diseases. 8: 165.

[23] Visser, M. E. Maartens G., Kossew G. and Hussey G. D.(2003). Plasma vitamin A and zinc levels in HIV-infected adults. British Journal of Nutrition. 89: 475-482.

[24] Fufa, H., Umeta, M., Taffesse, S., Mokhtar, N., Aguenaou, H.(2009) Nutritional and immunological status and their associations among HIV-infected adults. Addis Ababa, Ethiopia : The United Nations Universty. Food and Nutrition Bulletin. 30(3): 227-232.

[25] Amare, B., Tafess, K., Ota, F., Moges, F., Moges, B., Andualem, B., Yabutani, T and Kassu, A. (2011). Serum concentration of selenium in diarrheic patients with and without HIV/AIDS in Gondar, Northwest Ethiopia. $J$ AIDS Clinic Res 2:128.

[26] Ndeezi, G., Tumwine, K., Bolann, J., Ndugwa, M., Thorkild, T. (2010) Zinc status in HIV infected Ugandan children aged 1-5 years: a cross sectional baseline survey. BMC Pediatrics, 10 (68): $1-7$

[27] Ramadevi-Bhimavarapu, K. Priya Chitra, M. Ramaswamy, Prabhu Karunakaran, Ambati Brahma Reddy, B.Samyuktha Rani. (2010). Nutritional Status and Serum Zinc Levels in HIV Infected Individuals Compared to Control Participants Undergoing Anti Retro Viral Therapy (ART). Pharm. Sci. \& Res. 2 (11): 745-751

[28] Malviya, A., Hasan, H., Hussain, A. (2009). Correlation of CD4+ T cell count with serum Zinc, Copper and Selenium in HIV positive individuals. The Internet Journal of Epidemiology. 6:2. DOI: 10.5580/e5b

[29] Diaz Romero. C., Henr quez S., L pez Blanco F., Rodr guez R., Serra Majem L. (2002) Serum copper and zinc concentrations in a representative sample of the Canarian population. J Trace Elem Med Biol; 16:75-81. 